\title{
Kebijakan Pemerintah dalam Membendung Dampak Krisis Keuangan Global 2008
}

\author{
Oleh: Uzaifah
}

\author{
Judul: $\quad$ Memahami Krisis Keuangan: Bagaimana Harus Bersikeap \\ Penulis: Tim Penyusun Departemen Komunikasi dan Informatika \\ Penerbit: Departemen Komunikasi dan Informatika \\ Terbit: 2008 \\ Tebal: 79 halaman
}

\section{Pengantar}

Krisis keuangan global yang terjadi di Amerika tahun 2008 makin menjadi masalah serius. Sebagai negara dengan dominasi ekonomi ke seluruh dunia, krisis yang dialami Amerika akan sangat cepat menjalar ke berbagai negara. Tiongkok salah satu yang terparah, perekonomian mereka ikut goncang karena Amerika merupakan salah satu pangsa pasar ekspor terbesarnya mulai mengurangi nilai impor negaranya. Depresi yang saat ini tengah melanda dunia mengakibatkan bursa saham di beberapa negara terpaksa ditutup beberapa hari, termasuk di Indonesia. Harga-harga saham juga turut anjlok. Diperkirakan depresi ekonomi kali ini separah bahkan lebih parah dari depresi ekonomi tahun 1929. ${ }^{1}$

Kekuatan Amerika dalam dominasi keuangan dunia menjadikan Amerika memiliki keterkaitan dengan kegiatan ekonomi hampir di seluruh dunia. Didukung dengan sistem pasar bebas yang dianut hampir di seluruh negara di dunia, mengakibatkan goncangnya ekonomi Amerika cepat menjalarkan dampak negatifnya pada negara-negara yang terikat jalinan kerjasama keuangan dengan Amerika.

Berawal dari bangkrutnya investment banking Lehman Brothers, salah satu perusahaan raksasa yang memberiakan kucuran dana untuk kredit pemilikan rumah pada penduduk golongan subprime di Amerika Serikat. Keinginan meningkatkan laba perusahaan membawa beberapa perusahaan berani menempuh "seribu langkah" dengan berbagai tingkat risiko. Salah satunya adalah meluncurkan Subprime Mortgage $^{2}$. Pemberian istilah tersebut sangatlah tepat karena sasaran pemberian

•Dosen Tetap Prodi Ekonomi Islam Fakultas Ilmu Agama Islam UII Yogyakarta. Email: uza_ifah@yahoo.com.

${ }^{1}$ Cesarzc, Daftar Krisis Ekonomi Dunia Sepanjang Sejarah, dikutip dari http://cesarzc.wordpress.com/2008/10/11/daftar-krisis-ekonomi-sepanjang-sejarah/ accessed 6 April 2009.

2Subprime Mortgage adalah kredit perumahan yang diberikan kepada nasabah yang kurang layak. Pemerintah Amerika melakukan rating untuk mengukur tingkat kelayakan nasabah mendapatkan kredit perumahan. Minimal rating yang harus dimiliki nasabah adalah 600. Sedangkan dalam subprime mortgage, lembaga pemberi kredit berani mengucurkan kredit perumahan kepada nasabah dengan rating di bawah 500 dengan asumsi tetap rendahnya tingkat risiko dimana ketidakmampuan melanjutkan pembayaran kredit dapat diatasi dengan menyita barang kredit tersebut. 
Uzaifah: Kebijakan Pemerintah dalam Membendung...

kredit rumah adalah pada masyarakat dengan golongan subprime (dengan rating 500 yang sebenarnya menurut standar pemerintah Amerika belum memenuhi syarat untuk mengajukan kredit rumah). Namun, karena keinginan meningkatkan laba sangatlah besar, maka golongan subprime pun tetap ditawari kredit kepemilikan rumah.

Dampak yang sangat besar dari krisis keuanga di Amerika ini menjalar hampir di setiap negara baik di kawasan Amerika, Eropa, maupun Asia Pasifik. Namun, tidak seluruh perekonomian di kawasan Asia mengalami keterpurukan akibat dari krisis keuangan di Amerika. Berbeda dengan krisis keuangan yang terjadi pada tahun 1997 yang berdampak lokal dimana keterpurukan ekonomi hanya melanda beberapa negara di Asia, seperti Indonesia, Thailand, Malaysia, Singapura, Philipina, Korea Selatan. Krisis 2008 meluas ke hampir seluruh belahan dunia. Bursa saham berjatuhan. Perusahaan-perusahaan keuangan multinasional bangkrut. Banyak perusahaan di AS akan melakukan pengurangan pekerja. Akibatnya para investor portofolio di bursa saham menarik dananya sehingga bursa saham rontok semua dan kini nilai tukar mata uang Asia ikut rontok. Bahkan, nilai tukar rupiah terhadap dolar sempat mencapai level Rp12.000 per USD. Beruntung dan bersyukurlah bahwa pasar modal dan pasar uang Indonesia masih kuno sehingga dampak krisis global 2008 tidak menerpa kita hingga rontok. ${ }^{3}$

Pemerintah Indonesia masih optimis dapat meminimalisir dampak krisis keuangan Amerika terhadap stabilitas perekonomian Indonesia. Satu buktinya bahwa selama 1 Januari - 10 Oktober 2008, Rupiah hanya terdepresiasi sekitar 3\%, jauh di bawah nilai mata uang Philipina $(16 \%)$ dan juga Thailand $(17 \%)$. Hal ini menunjukan bahwa ekonomi kita masih terjaga menghadapi krisis ekonomi. ${ }^{4}$

Peran pemerintah sangatlah besar dalam usaha membendung dampak krisis keuangan global 2008 ini dari keterpurukan yang lebih parah. Selain sektor riil yang diperkuat oleh pemerintah, pemerintah juga telah mengeluarkan Peraturan Pemerintah Pengganti Undang-undang (Perpu) untuk mengatasi ancaman krisis keuangan global. Pertama, Perpu No. 2/2008 berisi tentang Perubahan Kedua UU No. 23 Tahun 1999 tentang Perubahan atas UU tentang Bank Indonesia. Kedua, Perpu No. 3/2008 tentang Mengubah Nilai Simpanan yang Dijamin Lembaga Penjamin Simpanan. Dan ketiga, Perpu No. 4/2008 tentang Jaring Pengaman Sistem Keuangan (JPSK). ${ }^{5}$

Lebih jauh dari semua langkah pemerintah dalam upaya membendung dampak krisis keuangan global yang lebih dalam, dibutuhkan ketenangan dalam menyikapi krisis keuangan yang terjadi sehingga rasionalitas dalam mencari solusi terjaga. Dengan tujuan tersebut, buku ini merupakan sarana yang tepat dalam tujuan sosialisasi kebijakan pemerintah kepada masyarakat agar masyarakat memahami, mengawasi, dan mendukung usaha pemerintah dalam membendung dampak negatif krisis keuangan yang tengah melanda dunia.

${ }^{3}$ Moh Arif Widarto, Krisis Kenangan Global 2008 Beda dengan Krisis Kenangan 1997, http://moharifwidarto.com/2008/10/krisis-keuangan-global-2008-beda-dengan-krisis-keuangan-1997/ accessed 6 April 2009

${ }^{4}$ Tim Penulis (2008), Memahami Krisis Keuangan: Bagaimana Harus Bersikap (Jakarta: Kementrian Komunikasi dan Informatika), p. 33.

${ }^{5}$ Tim Penulis (2008), Memahami Krisis Kenangan: Bagaimana Harus Bersikap Jakarta: Kementrian Komunikasi dan Informatika), p. 2.

Volume III, No. 1, Juli 2009 
Uzaifah: Kebijakan Pemerintah dalam Membendung...

\section{Krisis Keuangan Global}

Tatanan perekonomian di benua Amerika, Eropa, Asia Pasifik, Asia Selatan, bahkan Timur Tengah mengalami goncangan. Indeks harga saham gabungan dan nilai kurs di negara-negara tersebut ikut merosot drastis. Semua ini hanya sebagian dampak yang dirasakan dari krisis keuangan di Amerika Serikat yang meledak pada September 2008.

Ditandai dengan runtuhnya investment banking Lehman Brothers, disusul dengan ikut bangkrutnya perusahaan serupa yaitu Bear Stearns, Fannie Mae dan Freddie Mac, serta AIG. Investment banking adalah sebuah lembaga keuangan yang berkegiatan layaknya sebuah bank namun bukanlah bank seperti yang dipahami umumnya orang. Investment banking tidak terikat dengan peraturan bank, tapi bisa membuka produk-produk yang biasa ditawarkan perbankan bahkan semua produk yang ingin dikeluarkan sebuah investment banking. Dengan kebebasannya itu, salah satu jenis pembiayaannya adalah subprime mortgage yang sudah pasti tidak dapat dilakukan oleh lembaga perbangkan dalam arti sebenarnya.

Jauh dari perkiraan risiko yang diperhitungkan investment banking, ternyata pemberian subprime mortgage mengalami kegagalan sehingga mengakibatkan kebangkrutan. Lehman Brothers adalah salah satu investmen banking terbesar yang ada di Amerika, sehingga kebangkrutan Lehman Brothers menimbulkan dampak yang sangat luas.

Bermula dari subprime mortgage. Penduduk Amerika Serikat diberi peluang untuk mendapatkan kredit kepemilikan rumah walaupun masih di bawah standar kemampuan membayar cicilan kredit karena sebagian besar adalah tidak bekerja atau tidak mendapatkan penghasilan tetap. Keberanian pemberian subprime mortgage adalah karena bisa melakukan sita dan menjual kembali rumah apabila terjadi macet dalam angsuran kredit. Namun, skema tersebut malah sangat beresiko karena nasabah subprime mortgage banyak yang tidak mampu meneruskan kreditnya sehingga banyak rumah sitaan yang ketika dijual harga pasar properti sedang mengalami depresiasi.

Akibatnya, bank-bank di Amerika Serikat, Eropa, Asia (terutama Jepang), Australia, dan lembaga investasi teratas di dunia yang memiliki subprime mortgage securities ikut terkena dampaknya. Lembaga tersebut mengalami kerugian hingga miliaran dolar, sementara bank-bank dan lembaga investasi tersebut tercatat di bursa saham. Kondisi ini menyebabkan kejatuhan pasar saham di seluruh dunia. ${ }^{6}$

Selain kerugian bagi bank berskala global, terjadi pengeringan likuiditas di pasar modal dan perbankan global yang akan diiringi dengan penarikan dana baik yang berbentuk portofolio saham, obligasi maupun pinjaman dalam valuta asing sehingga pendanaan dalam valuta asing akan sangat sulit didapat dan menjadi mahal.

Sementara itu, ada beberapa negara akan terkena dampak langsung dari krisis keuangan global, terutama negara-negara di kawasan Eropa dan Asia Pasifik.

${ }^{6}$ Tim Penulis (2008), Tanya Jawab Memahami Krisis Kenangan Global: Bagaimana Pemerintah Mengantisipasinya (Jakarta: Kementrian Komunikasi dan Informatika), p. 3. 
Uzaifah: Kebijakan Pemerintah dalam Membendung...

Pertumbuhan ekonomi AS sebesar 2,0\% di tahun 2007 diperkirakan oleh The Fed akan mengalami perlambatan menjadi $1,3 \%$ di tahun 2008. Sementara itu, tingkat inflasi AS yang mencapai 2,9\% pada tahun 2007 diperkirakan meningkat menjadi 4,0\% di tahun 2008 dan inflasi di Eropa diperkirakan meningkat dari 2,1\% menjadi $3,6 \%$.

Tidak berbeda dengan di Amerika Serikat dimana Bank/Institusi Keuangan/Korporasi besar bangkrut, hampir di seluruh kawasan Eropa mengalami hal yang sama. Berbeda dengan kawasan Asia Pasifik, kebangkrutan Bank/Institusi Keuangan/Korporasi hanya dialami oleh Singapura dan negara lain di kawasan Asia Pasifik hanya mengalami kerugian pada Bank/Institusi Keuangan/Korporasi mereka. Namun, dampak lain seperti peningkatan inflasi, penurunan pertumbuhan ekonomi, dan runtuhnya indeks bursa saham sama dirasakan oleh sebagian negaranegara di kawasan Eropa dan Asia Pasifik. Negara di kawasan Eropa yang terkena dampak langsung krisis keuangan di Amerika Serikat adalah Islandia, Rusia, Belanda, Inggris, Perancis, dan Jerman. Sedangkan negara di kawasan Asia Pasifik yang terkena dampaknya adalah Cina, Taiwan, Singapura, Jepang, dan Australia.

Secara tidak langsung, Indonesia tidak luput terkena dampak krisis keuangan di Amerika. Dua komoditi ekspor utama Indonesia diekspor ke Amerika, yaitu CPO (Crude Palm Oi) dan Batubara (Coe). CPO di Pasar Rotterdam mengalami penurunan harga dari USD1,207 per metrik ton di bulan Juni 2008, menjadi USD705 per metrik ton di bulan September 2008. Sementara, batubara (coal) di Pasar US Spot Big Sandy juga mengalami penurunan harga dari USD133,5 per short ton pada Juni 2008 menjadi USD112,5 per short ton pada September 2008.7

\section{Ketahanan Ekonomi Indonesia}

Bertahannya Indonesia dari serangan krisis keuangan global merupakan hal yang melegakan. Berbeda dengan krisis keuangan yang terjadi pada tahun 1997. Indonesia mengalami kemerosotan ekonomi yang sangat drastis. Penyebab utama dari terjadinya krisis 1997 yang berkepanjangan adalah merosotnya nilai tukar rupiah terhadap dolar AS yang sangat tajam. Dampaknya pun menjalar, dari kesulitan menutup APBN, harga telur/ayam naik, utang luar negeri dalam rupiah melonjak, harga BBM/tarif listrik naik, tarif angkutan naik, perusahaan tutup atau mengurangi produksinya karena tidak bisa menjual barangnya dan beban utang yang tinggi, toko sepi, PHK di mana-mana, investasi menurun karena impor barang modal menjadi mahal, biaya sekolah di luar negeri melonjak. Dampak lain adalah laju inflasi yang tinggi selama beberapa bulan terakhir ini, yang bukan disebabkan karena imported inflation, tetapi lebih tepat jika dikatakan foreign exchange induced inflation. ${ }^{8}$

Belajar dari dampak yang cukup parah dirasakan Indonesia pada krisis keuangan tahun 1997, Indonesia melakukan pembenahan perekonomian dengan

\footnotetext{
7 Tim Penulis (2008), Tanya Jawab Memahami Krisis Kenangan Global: Bagaimana Pemerintab Mengantisipasinya (Jakarta: Kementrian Komunikasi dan Informatika), p. 7.

8 Tim Redaksi, Krisis Ekonomi Indonesia: Terjadinya, Dampaknya, dan Pemecahannya dikutip dari http://www.mie.unja.ac.id/pustaka/bahanepb.doc/ accessed 6 April 2009.
} 
Uzaifah: Kebijakan Pemerintah dalam Membendung...

memperkuat sektor-sektor fundamental perekonomian. Hasilnya, ketika krisis keuangan global 2008 datang, Indonesia mampu bertahan dari dampak yang sangat dalam. Seperti yang disajikan dalam buku ini, ada beberapa indikator ekonomi yang menjadi penguat perekonomin dari serangan krisis keuangan tahun 2008, yaitu:

1. Pertumbuhan ekonomi Indonesia meningkat dari 5,5\% di tahun 2006 menjadi 6,3\% di tahun 2008.

2. Ekonomi Indonesia masih tumbuh 6,4\% pada awal tahun 2008 melalui tiga sektor, yaitu pertanian, pengangkutan dan telekomunikasi, dan sektor listrik, air bersih dan gas.

3. Pertumbuhan konsumsi meningkat $3,2 \%$ di tahun 2006 menjadi $5,0 \%$ pada tahun 2007 dan diprediksikan akan terus meningkat sampai dengan tahun 2009.

4. Pembentukan modal tetap bruto meningkat tajam dari $2,5 \%$ di tahun 2006 menjadi 9,2\% di tahun 2007.

5. Pengeluaran pemerintah menurun dari $9,6 \%$ menjadi $3,9 \%$.

6. Pertumbuhan sektor pertanian meningkat dari 3,4\% (2006) menjadi $3,5 \%$ (2007).

7. Terkendalinya nilai tukar rupiah terhadap dolar Amerika (USD).

8. Laju inflasi relatif terkendali. Inflasi di Indonesia pada waktu itu sempat tinggi yaitu 12,14\% (September 2008) karena bertepatan dengan bulan Ramadhan dan I'dul Fitri.

9. Menurunnya suku bunga (BI Rate).

10. Penerimaan dalam negeri (pajak) terus meningkat.

Dengan fundamental ekonomi Indonesia yang sudah cukup kuat sebelum terjadinya krisis keuangan global, Indonesia yakin mampu menjaga perekonomian dalam negeri dalam kondisi stabil walaupun sudah pasti tetap merasakan imbas krisis keuangan global ini.

Nilai ekspor Indonesia pada bulan Agustus 2008 mengalami penurunan mencapai USD 12,5 miliar dibanding bulan Juli 2008. Namun secara keseluruhan, nilai ekspor Indonesia meningkat $29,9 \%$ dari tahun 2007 . Hal ini karena Indonesia yang memperluas pasar ekspornya, tidak hanya melakukan ekspor dalam jumlah yang besar ke kawasan Amerika dan Eropa saja, namun juga melakukan ekspor ke Asia, Jepang, dan Singapura sehingga dampak krisis yang melanda Amerika tidak langsung dirasakan karena ekspor ke tiga negara terakhir itu cukup stabil.

Kondisi moneter Indonesia cukup stabil. Tingkat likuiditas perbankan masih terjaga walaupun masing-masing bank lebih ketat menjaga likuditas banknya karena kekhawatiran akan terimbas dampak krisis keuangan global yang sedang melanda sehingga transaksi peminjaman dana segar antar bank untuk sementara sangat sulit berjalan. Tingkat inflasi yang terjaga pada tingkat 6,6\% antara tahun 2006-2007 meningkat menjadi 10,47\% pada akhir September 2008. Namun, kenaikan inflasi ini lebih disebabkan peningkatan harga minyak dunia. 
Uzaifah: Kebijakan Pemerintah dalam Membendung...

\section{Langkah Penyelamatan Perekonomian Indonesia}

Seperti telah diuraikan sebelumnya. Krisis keuangan yang tengah melanda dunia sekarang ini pasti akan menimbulkan dampak negatif bagi setiap negara walaupun berbeda ukurannya, termasuk Indonesia. Dampak langsung yang dirasakan Indonesia adalah hanya kerugian yang dialami Lembaga Keuangan Indonesia yang menanam dana pada investment banking Lehman Brothers. Sedangkan secara tidak langsung, dampak krisis keuangan global tetap akan memberikan pengaruh pada perekonomian Indonesia, seperti yang disebutkan dalam buku ini, yaitu: ${ }^{9}$

1. Mempengaruhi momentum pertumbuhan ekonomi Indonesia dalam bentuk pengeringan likuiditas, lonjakan suku bunga, anjloknya harga komoditas, dan melemahnya pertumbuhan sumber dana.

2. Menurunnya tingkat kepercayaan konsumen, investor, dan pasar terhadap berbagai institusi keuangan yang ada.

3. Flight to equity, pasar modal Indonesia terkoreksi akibat indikasi melemahnya mata uang rupiah.

4. Kurangnya pasokan likuiditas di sektor keuangan karena kebangkrutan berbagai institusi keuangan global.

5. Menurunnya tingkat permintaan dan harga komoditas utama ekspor Indonesia tanpa diimbangi peredam laju impor secara signifikan akan menyebabkan defisit perdagangan yang semakin melebar dalam selang waktu mendatang.

6. Kesulitan penggalangan capital inflow dalam jumlah besar.

Melalui buku ini, pemerintah mensosialisasikan kebijakannya yang merupakan action dari arahan presiden kepada jajaran Menteri Kabinet Indonesia Bersatu dan para Pimpinan BUMN yang bertujuan mempertahankan kestabilan pertumbuhan ekonomi Indonesia. Arahan dimaksud adalah:10

1. Semua kalangan harus tetap optimis, dan besinergi untuk memelihara momentum pertumbuhan ekonomi dan mengelola serta mengatasi dampak krisis keuangan yang terjadi di Amerika Serikat. Oleh karena itu kita semua tidak boleh panik dan harus tetap menjaga kepercayaan masyarakat.

2. Dengan kebijakan dan tindakan yang tepat, serta dengan kerja keras dan upaya maksimal, nilai pertumbuhan ekonomi tetap dipertahankan sebesar $6 \%$. Komponen yang perlu dijaga antara lain: konsumsi, belanja pemerintah, investasi, ekspor, dan impor. Tindakan yang perlu dilakukan adalah pemanfaatan perekonomian domestik dan mengambil pelajaran dari krisis 1997, dimana sabuk pengaman perekonomian Indonesia adalah sektor UMKM, pertanian, dan sektor informal.

9 Tim Penulis (2008), Memahami Krisis Keuangan: Bagaimana Harus Bersikap Jakarta: Kementrian Komunikasi dan Informatika), p. 33.

${ }^{10}$ Ibid., p. 36.

Volume III, No. 1, Juli 2009

La_Riba 125

JURNAL EKONOMI ISLAM 
Uzaifah: Kebijakan Pemerintah dalam Membendung...

3. Optimasi APBN 2009 untuk memacu pertumbuhan dan membangun social safety net. Hal-hal yang harus diperhatikan yaitu:

a. Penyediaan infrastruktur dan stimulasi pertumbuhan.

b. Alokasi anggaran penanggulangan kemiskinan tetap menjadi prioritas.

c. Defisit anggaran harus tepat dan rasional atau tidak mengganggu pencapaian sasaran kembali (growth with equity).

4. Dunia usaha khususnya sektor riil harus tetap bergerak, agar penerimaan negara tetap terjaga dan pengangguran tidak bertambah.

5. Semua pihak agar cerdas menagkap peluang untuk melakukan perdagangan dan kerjasama ekonomi dengan negara sahabat.

6. Galakan kembali penggunaan produk dalam negeri sehingga pasar domestik akan bertambah kuat.

7. Memperkokoh sinergi dan kemitraan pemerintah dengan perbankan dan pemerintah dengan perbankan dan dunia usaha.

8. Semua kalangan diminta menghindari sikap egosektoral dan memandang remeh masalah. Presiden menegaskan pentingnya kerjasana yang terkoordinir antar instansi terkait.

9. Mengutamakan kepentingan rakyat di atas kepentingan golongan dan pribadi.

10. Semua pihak diminta melakukan komunikasi dengan tepat dan bijak kepada masyarakat.

Sepuluh arahan presiden di atas diimplementasikan dalam langkah-langkah kebijakan pemerintah. Langkah kebijakan tersebut adalah:

1. Kepastian hukum dan jaminan investasi.

2. Perkuat dan jaga ketahanan sektor riil.

3. Stabilisasi moneter melalui peningkatan nilai penjaminan nasabah dalam satu bank.

Selanjutnya, pihak eksekutif akan mengambil langkah-langkah kontigensi yang dibutuhkan melalui penerbitan Perpu, antara lain:

1. Peraturan Pemerintah Pengganti Undang-undang No. 2/2008 tentang Perubahan Kedua Atas Undang-undang No. 3/2008 tentang Bank Indonesia.

2. Peraturan Pemerintah Pengganti Undang-undang No. 3/2008 tentang Lembaga Penjamin Simpanan.

3. Peraturan Pemerintah No. 4/2008 tentang JPSK.

4. Percepatan Perumusan RUU Financial Savety Net.

5. Program Jaring Pengaman Sosial.

Arahan, langkah-langkah kebijakan, dan langkah-langkah kontigensi yang diambil jajaran eksekutif di atas merupakan langkah-langkah yang diambil pemerintah sebagai benteng bagi perekonomian Indonesia dalam menghadapi krisis keuangan yang tengah dilanda dunia. 
Uzaifah: Kebijakan Pemerintah dalam Membendung...

\section{Penutup}

Dalam menghadapi krisis keuangan global dibutuhkan kecerdasan dan ketenangan. Pemerintah sebagai aparatur negara harus lebih keras lagi memikirkan solusi dalam menghadapi dan tentunya membentengi negaranya dari dampak yang dapat ditimbulkan dari krisis keuangan global yang terjadi di tahun 2008, terutama dalam menjaga stabilitas perekonomian.

Belajar dari krisis keuangan 1997, pemerintah mulai membenahi fundamental ekonomi sehingga diharapkan lebih kuat apabila kelak terjadi krisis lagi. Krisis tahun 1997 menimbulkan dampak yang sangat signifikan bagi Indonesia. Dampak jangka panjang dari krisis tahun 1997 adalah jumlah keluarga miskin diperkirakan meningkat menjadi 7,5 juta. ${ }^{11}$ Terbukti ketika krisis keuangan terjadi kembali pada tahun 2008 ini, perekonomian Indonesia tidak terlalu terpengaruh dan dapat bertahan dari terpaan krisis keuangan global. Bertahannya Indonesia dari keterpurukan ekonomi akibat krisis keuangan global selain karena sudah kuatnya fundamental perekonomian Indonesia, juga karena pemerintah cekatan dalam merespon kejadian ekonomi dunia dengan kebijakan-kebijakan yang diambil. Namun, pemerintah tetap membutuhkan bantuan masyarakat melalui dukungan dalam melaksanakan kebijakan yang sudah dibuat.

Buku ini adalah sarana pemerintah guna mendapatkan kesatuan aksi dengan masyarakat. Pemerintah Indonesia berharap rakyat bisa mengerti tujuan dari kebijakan-kebijakan yang diambil pemerintah dalam rangka penyelamatan perekonomian Indonesia dari efek domino krisis keuangan global tahun 2008 ini. Pemerintah juga berharap agar rakyat berpartisipasi aktif mendukung program pemerintah tersebut sehingga proses penyelamatan ekonomi dapat lebih cepat terwujud.

Dibalik dari sisi konten buku ini yang sangat bermanfaat bagi usaha peningkatan kualitas komunikasi antara pemerintah dan rakyat, hendaknya untuk edisi cetak berikutnya tim penulis lebih menjaga konsistensi tulisan. Tim penulis masih belum konsisten menyampaikan informasi dengan menggunakan kata atau istilah yang berbeda, yaitu pada saat menerangkan kebijakan berbagai negara dalam mengatasi dampak krisis keuangan global, penulis menggunakan kata "menurun" untuk perubahan angka dari yang rendah ke tinggi, sedangkan pada halaman berikutnya, istilah "menurun" digunakan untuk perubahan angka dari yang tinggi ke rendah.

Sangat disayangkan pula, buku ini tidak sedikitpun menyebutkan peran ekonomi Islam khususnya perbankan dalam menghadang krisis keuangan global tahun 2008 ini. Padahal, keberadaan perbankan syari'ah merupakan salah satu sektor keuangan yang memberikan sumbangan besar dalam penguatan ekonomi pada sektor riil. Dibuktikan, kinerja pertumbuhan pembiayaan bank syari'ah tetap tinggi sampai posisi Februari 2009 dengan kinerja pembiayaan yang baik (NPF, Net Performing Financing di bawah 5\%). Penyaluran pembiayaan oleh perbankan syari'ah per Februari 2009 secara konsisten terus mengalami peningkatan dengan

11 Tim Redaksi, Krisis Ekonomi Indonesia: Terjadinya, Dampaknya, dan Pemecahannya dikutip dari http://www.mie.unja.ac.id/pustaka/bahanepb.doc/ accessed 6 April 2009. 
Uzaifah: Kebijakan Pemerintah dalam Membendung...

pertumbuhan sebesar 33,3\% pada Februari 2008 menjadi 47,3\% pada Februari 2009. Sementara itu, nilai pembiayaan yang disalurkan oleh perbankan syari'ah mencapai Rp.40,2 triliun.

Sekali lagi industri perbankan syari'ah menunjukkan ketangguhannya sebagai salah satu pilar penyokong stabilitas sistem keuangan nasional. Dengan kinerja pertumbuhan industri yang mencapai rata-rata $46,32 \%$ dalam lima tahun terakhir, iB (baca ai-Bi, Islamic Bank) di Indonesia diperkirakan tetap akan mengalami pertumbuhan yang cukup tinggi pada tahun 2009.

Bersamaan dengan diterbitkannya buku ini, pemerintah di bawah lembaga yang sama juga menerbitkan sebuah buku terkait krisis keuangan global tahun 2008 . Buku dimaksud berjudul "Tanya Jawab Memahami Krisis Keuangan Global, Bagaimana Pemerintah Mengantisipasinya". Buku tersebut merupakan buku pendukung karena berisi ungkapan rakyat tentang kekhawatiran dan keinginan tahuan terhadap krisis keuangan global yang sedang terjadi.

\section{DAFTAR PUSTAKA}

Tim Redaksi, Krisis Ekonomi Indonesia: Terjadinya, Dampaknya, dan Pemecabannya dikutip dari http://www.mie.unja.ac.id/pustaka/bahanepb.doc/accessed 6 April 2009.

Tim Redaksi, Perbankan Syari'ab: Lebih Taban Krisis Global dikutip dari http://www.bi.go.id/NR/rdonlyres/2FA608A9-DDFE-4551-884DD0B9D5965572/17639/Perbankan_Syari'ah_Lebih_Tahan_Krisis_Global.p df/ accessed 6 April 2009.

Cesarzc, Daftar Krisis Ekonomi Dunia Sepanjang Sejarah dikutip dari http://cesarzc.wordpress.com/2008/10/11/daftar-krisis-ekonomisepanjang-sejarah/ accessed 6 April 2009.

Moh Arif Widarto, Krisis Kenangan Global 2008 Beda dengan Krisis Kenangan 1997 dikutip dari http://moharifwidarto.com/2008/10/krisis-keuangan-global2008-beda-dengan-krisis-keuangan-1997/accessed 6 April 2009.

Tim Penulis (2008), Memahami Krisis Kenangan: Bagaimana Harus Bersikap, Jakarta: Kementrian Komunikasi dan Informatika.

Tim Penulis (2008), Tanya Jawab Memahami Krisis Kenangan Global: Bagaimana Pemerintah Mengantisipasinya, Jakarta: Kementrian Komunikasi dan Informatika. 